of modifications of known procedures were described. In particular, Mittelmann has used a method involving the preliminary determination of the effective resistance of the circuit with a secondary transmitter and valve voltmeter, followed by measurement of $I$ or $E$ during treatment with thermo-cross and dynamometer. Riesinger measures the total anode dissipation of his transmitter with ammeter and volt. meter, and the heat dissipation with a photo-cell and a reflecting bimetal strip fixed to the anode, the difference representing the high-frequency energy generated. It seems, however, uncertain whether this arrangement can be used, as Riesinger claims, as a dose intensity indicator. Schwarz suggested two rapid methods : first, determination of 'spread' of the resonance curve by means of variable condenser and Braun tube; secondly, measurement of true field across the object by small electrometer electrodes mounted in the condenser plates. The papers on the subject gave the impression, however, that the problem is still far from being solved.

J. B. Bateman.

\title{
The Science of Archives in South Africa*
}

$\mathrm{S}^{\mathrm{T}}$ UDY and work connected with archives have been recognized as a science, and a scientific system of keeping archives has been evolved; while not only is a high standard of attainment and a wide range of knowledge of scientific method and results demanded of the archivist, but also in certain European countries provision has been made for his technical training.

Archives constitute a fundamental source of historical information, and hence the introduction of the moving picture-the cinematograph film and the 'talkies' have, in the problem of their conservation, forced on the attention of the archivist a number of practical questions, the method of dealing with which has yet to be determined on scientific lines.

In South Africa, prior to the date of the Union, the Cape Province gave attention to this subject more than half a century ago, and the Transvaal since about 1902. In 1919 the Union Government took the first serious step in co-ordinating the archives of the four provinces.

The administration of Union and Provincial Archives was centralized in a chief archivist, and by legislation of 1922 Union and Provincial archive depots were created, the former at the seat of government of the Union, and the latter at the seat of the Provincial administration. The centres thus are in Cape Town, Pretoria, Pietermaritzburg and Bloem. fontein, each in charge of an archivist, and the whole administration centralized in the chief archivist. This system secures uniformity of administration, arrangement, classification, inventorying, methods of preservation and general care. It has resulted in straightforward administrative efficiency, and experience has taught that it is the only satisfactory method. Experts in archive economy the world over endorse this system.

The Archives Department is a young branch of the Public Service of the Union of South Africa. Its advance, unspectacular but steady, during the last decade or so, was marked by a persistent claim to recognition as an integral part of the Government machinery and the necessity for its personnel to be men with a certain standard of education and an aptitude for the work.

An archives depot is not static, and must increase in quantity and quality as the years pass. The

* Substance of the presidential address to the South African Association for the Advancement of Science, at the Windhoek meeting on July 5, 1937, by Lieut.-Colonel C. Graham Botha, chief arehivist of the Union of South Africa.
Department was conceived, no doubt, as a branch of the service with great possibilities. Its growth was slow at first, and to some extent stunted because it had to overcome many prejudices. When it was given a place in the Government machinery, it had to live down the prevalent conception that it was a warehouse for the storage of records with someone in charge to keep them from deterioration and permit their consultation when necessary. It had to have a proper home and the right kind of vitamins in its food to allow it to develop. But this stripling of a department struggled on, facing all the obstacles which beset it.

South Africa had the advantage of studying the systems of similar institutions of older and more experienced countries. It avoided the pitfalls made by them in the past and took the best from each country and adapted this to suit the conditions in South Africa. Other sections of the British Commonwealth of Nations afterwards gave attention to the organization of their national records, such as the Commonwealth of Australia and the Dominion of New Zealand. The most recent recruit is the Colony of Southern Rhodesia, which created an Archives Department by legislation a few years ago. From the three countries, inquiries came to South Africa regarding the system of keeping archives which was being adopted.

Within the last ten years, the archives at Capo Town, Pietermaritzburg and Bloemfontein have been transferred to their buildings with up-to-date equipment and protective devices at a cost of many tens of thousands of pounds. Steps are being taken to provide a separate building at Pretoria, which will house the Provincial archives and contain the records of the Union Government, when old enough for the transfer so laid down by law.

To illustrate the growth of this branch of the service during the last eighteen years, personnel and salary expenditure have increased from a staff of five and an expenditure of $£ 2,800$ in 1919 , to a staff of 42 and an expenditure of $£ 11,000$ in 1937. The number of researchers and visitors and volumes con. sulted during the last five years indicates a steady and encouraging increase.

The system for the arrangement and classification of the archives in South Africa is that recognized in Europe, and referred to as the 'principe des fonds', in which the system of classification is based on the department of origin. Experience has shown that this is the only sound one. 
Colonel Botha described the duties of the archivist in relation to arrangement, classification, inventory and catalogue, and touched upon the physical defence of archives, covering the repository and accommodation, and their moral defence, referring to their reception and arrangement, in which he must study the administrations concerned, their history and organization, and divide them into classes and subdivisions of these ; while the secondary duty of the archivist relating to the special requirements of the student covers the preparation of guides, lists, inventories and catalogues of his archives. Full transcripts must be prepared and published under an editor to meet the needs of the student resident at a distance. $\mathrm{He}$ also dealt with the problem of selection and destruction.

Finally, in illustration of his contention that archives are the material of history, Colonel Botha outlined from the records preserved in the archives, the history of the national roads in South Africa, the creation of a rational road fund, and the constitution of a National Road Board in 1935, of which the story is disclosed in the archives by records of South Africa's early road system and its administration from the seventeenth century onward.

In conclusion, the science of archives may be likened to a venerable sage, who seeks for the authentic traces of man and his doings in the past and, finding them, preserves and jealously guards them. His eyes are glowing with wisdom drawn from the mass of evidence of man's past accomplishments, his failures and successes, as treasured up by him with tender care; ever ready to reach a helping hand to men of the present day in their struggles to move onward the ship of human progress, often doing so with an encouraging smile and reference to the Solomon of Biblical times : "there is nothing new under the sun" ; and he appeals insistent ly to one and all to view the present unfolding of our grand and wonderful universe in the light of the ages gone by.

\section{Science News a Century Ago}

\section{Lyell in Germany}

Writing from Wesel on the Rhine on August 29, 1837 , to Darwin, Lyell said, "I write this to you, at least $I$ am beginning it, in a steamboat on the Rhine, so make allowance for the tremulous motion. We came in a steamer from Copenhagen to Lübock, then in a hired carriage to Hamburgh, across the sand and boulder formation of the Baltic, which for the most part we have been on ever since, although we have crossed the Weser, and Ems, and Lippe. The blocks of red syenitic granite, which I hammered away at in Norway, and which I saw there in situ sending its veins into the trilobite and orthoceratite schist, have been carried with small gravel of the same, by ice of course, over the south of Norway, and thence down the south.west of Sweden, and all over Jutland and Holstein, down to the Elbe, from whence they came to the Weser, and so on to this or near this. . . .

"This then was already dry land when Holstein, and all from the Baltic as far as Osnabruck or the Teutobarger Wald hills, was submerged. At Bremen I saw Olbers, aged seventy-two, the astronomer who discovered Pallas and Vesta, and at Osnabruck and Münster I met a warm and German reception from men of whom I had never heard, who had read my paper on Sweden or something else. I mean by German, that kind of frank expression of enthusiasm for science, or of any emotion, which a well-bred Englishman tries to suppress, at least all outward expression of it, from the dread of being thought ridiculous, or of affecting to feel more than he does, or from mauvaise honte. If you ever get sick of that fashionable nonchalance which would blush to admire anything, or at least to confess it, I advise you to plunge into Germany, and you will be soon refreshed and brought back to the right tone again, whether it be literature, science, or any other pursuit you are following. ...",

\section{The First Steam Frigate}

ON August 31, 1837, H.M.S. Gorgon, the first steam vessel in the Royal Navy designed as a frigate, was launched at Pembroke. Designed by Captain (afterwards Admiral) Sir William Symonds, the Surveyor of the Navy, the Gorgon was $178 \mathrm{ft}$. long, $37 \frac{1}{2} \mathrm{ft}$. beam and 1,108 tons burthen by the rule known as Builders' Old Measurement. She was noteworthy not only as being designed as a frigate, but also as being the first vessel in the Navy to be fitted with John Seaward's direct-acting engine, instead of a side-lever engine, by which a considerable saving of weight was offected. The cylinders were placed directly beneath the crankshaft driving the paddle wheels. They were 64 in. diameter with a stroke of $5 \frac{1}{2} \mathrm{ft}$., the engine being of 320 nominal horse-power. The boiler pressure was $5 \mathrm{lb}$. per square inch. The total weight of the machinery, including the water in the boilers, was 276 tons. Service in such vessels was eagerly sought after by far-sighted young naval officers, and among those who served in the Gorgon was Admiral Sir Astley Cooper Key, who as a lieutenant exchanged from the Curaçoa into the Gorgon and in doing so spoke of it as almost a change of profession. "Being in a steamer", he wrote, "has given me a much greater interest in the service than I had before, from having, I suppose, an object in view to which I feel myself suited." On another occasion he wrote, "I study De Pambour and Tredgold daily".

\section{The British Association at Liverpool}

IN its issue of September 2, 1837, the Athenceum, referring to the forthcoming meeting of the British Association at Liverpool, said that while there had been no doubt as to the really excellent fruits of the morning meetings, the same satisfaction had not been felt regarding the evening meetings, which had been intended for diffusing among the general body of members "some part of the treasures of knowledge collected and purified in each Section". There was therefore to be a change of plan. "The great want of opportunity for cultivating mutual acquaintance and enjoying friendly discussion--a desideratum felt with increased force at every Meeting succeeding the embryo sitting at York-will be met by devoting at least two evenings to a pleasurable Promenade and Conversazione in the magnificent apartments of the Town Hall, which the Mayor and Council have most liberally placed at the disposition of the Association. Thus the evenings may offer an agreeable relaxation after the morning work-the men of abstract and practical knowledge may be mingled together, and both brought into friendly intercourse with those numerous friends of the Association who attend the meetings to gather knowledge, and those whom they esteem as leaders of science." 